\title{
IMPACT OF SLASH PILE SIZE AND BURNING ON PONDEROSA PINE FOREST SOIL PHYSICAL CHARACTERISTICS
}

\author{
Geoff Seymour and Aregai Tecle ${ }^{1}$
}

Continuous fire suppression and a policy of limited to no harvesting have made forests in the Intermountain West overcrowded and dangerously susceptible to wildfire and other forest health risks (Martin et al. 1979; Mutch et al. 1993; Pyne et al. 1996; Sackett et al. 1996). To reduce these hazards, forest resources researchers and managers are restoring unhealthy forests through thinning and burning (Brown et al. 1977; Snell and Brown 1980; Freeman et al. 1982; Debano et al. 1998). However, burning slash piles associated with forest thinning prescriptions may result in unintended effects to site characteristics in the treated areas. Changes in soil physical characteristics created by either piling slash or burning the slash piles may contribute to floral community change, if not driving the change, by affecting water and nutrient pathways and light and water interception (DeBano et al. 1998; Neary et al. 1999). Therefore, physical changes in soils would likely result in habitat reduction for native fauna, and may have broad implications for ecological functions, processes, and management. This study evaluates soil physical characteristics that can affect floral species establishment following the slash pile burns associated with restoration thinning treatments.

Forest restoration in much of the Intermountain West involves thinning trees to reduce fuel loads in the forested areas. The practice of forest thinning or harvesting for restoration purposes creates large amounts of unmarketable woody debris, or slash, which is often piled and removed through chipping or burning (Smith et al. 1997; DeBano et al. 1998). In most cases prescribed burns remove the slash that results from thinning, as well as most of the accumulated forest floor fuel load (Covington et al. 1997; USDA 1998). Severe soil damage can occur under these burn piles due to intense soil heating; however, the damage is limited to the

${ }^{1}$ School of Forestry, Northern Arizona University local area under the piles (DeBano et al. 1998). In spite of this, fire is considered an appropriate method to remove slash because wildfire historically consumed the dead fallen branches that comprise the majority of the slash piles (DeBano et al. 1998; USFS 1998). Land managers generally prefer to burn slash in piles not only to reduce harvesting-related residual fuels that become fire hazards, but also because piles burn more efficiently with less smoke and they can do so under broader weather conditions than broadcast burning of slash (Hardy 1966).

\section{OBJECTIVES}

Burning slash piles associated with forest thinning prescriptions may result in varying soil physical characteristics. The objective of this particular study is to determine the effect of burning slash piles on soil bulk density, water infiltration capacity, and soil moisture content. We expect slower water infiltration in the burned soils due to an increased amount of the fine particles that fill macropores in the soil (ash from burned slash) and the formation of a hydrophobic layer from the intense heat that bakes the organic material in the forest floor. The expected increase in soil fines would increase the soil bulk density. Furthermore, fire consumption of most, if not all, of the organic matter in and above the soil can lower the soil moisture conditions in the burned plots because the organic materials that had a large water holding capacity are burned.

Another factor that may affect soil physical characteristics is the size of slash piles. The U.S. Forest Service has no specific guidelines for piling slash, so individual ranger districts pile slash as they see best fit for the area. Currently the Flagstaff area uses two sizes of hand-piled slash piles. The Peaks Ranger District in the Coconino National Forest tends to build smaller piles, less than $1.5 \mathrm{~m}$ $(5 \mathrm{ft})$ high and $3 \mathrm{~m}(10 \mathrm{ft})$ wide at the base, whereas the adjacent Mormon Lake Ranger District tends to 
build larger and wider piles, in excess of $3 \mathrm{~m}(10 \mathrm{ft})$ wide and at least $2 \mathrm{~m}(6 \mathrm{ft})$ high. Due to the increased amount of fuel wood and subsequently more heat production in the larger burn piles compared to the smaller piles, we further hypothesize that the expected effects described above will be greater under the larger piles than under the smaller piles.

The experiment was conducted on the grounds of The Arboretum at Flagstaff, approximately 6 miles west of Flagstaff, Arizona, within the ponderosa pine (Pinus ponderosa)/Arizona fescue (Festuca arizonica) forest type. The slash piles were constructed from ponderosa pine slash material that was left on the forested grounds of the arboretum. The piles were remains of a forest restoration thinning that occurred in 1999, in which approximately a third of the forest density was removed. An important note to make here is that the burning of these piles occurred in conjunction with further thinning in August 2001 by the Flagstaff Fuels Management Team, in which an additional third of the original basal area was removed.

The soils of the study area are typic or mollic eutroboralfs; these soils tend to be moderately deep $(50-100 \mathrm{~cm})$ and have textures that range from a gravelly to a very cobbly loam (USDA 1995). Gravel is a rock fragment that ranges in size from $2 \mathrm{~mm}$ to $8 \mathrm{~cm}$, whereas cobble ranges from 8 $\mathrm{cm}$ to $25 \mathrm{~cm}$ in size (Fisher and Binkley 2000). Rock fragments larger than $2 \mathrm{~mm}$ make up more than 30 percent of the gravelly soils and half of the very cobbly soils. Generally, the slopes associated with these soil types range from 0 to 15 percent.

\section{SOIL PHYSICAL CHARACTERISTICS}

Blake and Hartge (1986) defined bulk density as the ratio of the mass of oven-dried soil solids to the bulk volume of the solids plus the pore space, with the moisture content present during the sampling period. Bulk density can be used to calculate soil porosity (pore space in a soil), to convert weights to volumes, and to estimate weights of soil on landscape scales (Carter 1993).

Infiltration is the process of water entering the soil generally from the soil surface and moving downward (Hillel 1971). Infiltration capacity is the maximum rate of infiltration that can pass through the soil under standing water conditions. This rate is quite important because it often determines the amount of runoff that might occur after a rain event or snowmelt (Hillel 1971). But perhaps more important, infiltration capacity determines how much, and how quickly, surface water becomes available to plants. Knowledge of rate of infiltration is also important because it can be used to identify soil properties such as relative bulk density, porosity, and compaction below the soil surface. In this study, we use infiltration capacity to determine whether a layer of hydrophobic compounds in the soil has created a water-repellent layer that would seal off, or retard infiltration. If a water-repellent layer exists, infiltration capacity also helps to determine the relative depth of the layer associated with a given treatment. When a hydrophobic layer is created, the infiltrating water essentially stops when the surface soil above the hydrophobic layer becomes saturated. When the retarding effect of the hydrophobic layer is overcome, the rate of infiltration will increase until it reaches some steady-state rate.

One of the most significant physical alterations that may occur in burned soils is an increase in soil water repellency. Water repellency in soils was first noted in the mid 1800s (Bayliss 1911), when the water-repellent effect of soil fungi (specifically mycelium) was observed. The phenomenon that drew the researchers' attention during that time was a condition termed "fairy ring," which describes an approximately circular spatial formation of plants where growth inside the circle appears stimulated. The structure could be so distinct that outside the circle, only bare ground or withered plants occur. In the late 1800 s soil moisture was found to be the reason for the formation of such rings. The soil moisture inside the circle of healthy plants was higher than that of the surrounding soil (Lawes et al. 1883). Molliard (1910) reported that soils with mycelium fungi contained only 5-7 percent soil moisture, compared to 21 percent in areas without the mycelium fungi. Bayliss (1911) provided a case study in which rain did not penetrate into mycelia-infested soils, whereas it penetrated into mycelia-free areas to a depth of $10 \mathrm{~cm}$.

Other mechanisms (such as volatilizing organic materials) may be responsible for any post-fire water repellency in the ponderosa pine forest type. This water-repellent soil (hydrophobic soil) is often found on the surface or a few centimeters below and parallel to the surface (DeBano et al. 1998). Hydrophobic conditions in mineral soils are characteristically found under a layer of severely burned soil or an ash layer (DeBano 1969). Heat from fires burning the litter layer on the soil surface forms these hydrophobic soils. This intense heat also vaporizes some of the burned organic compounds, which are then pushed down into the soil by heat radiation until they reach a cooler soil 
layer where they condense in the space between the soil particles in that layer. In this way the organic compounds coat the soil particles, which can then adhere to each other to from a barrier against infiltrating water. Research into hydrophobic soils created by fire began in the 1950s and accelerated in the 1960s (Debano 2000a). Shortly thereafter, DeBano and Krammes hypothesized that soil particles were more efficiently coated with organic compounds at lower temperatures and for shorter time periods than at higher temperatures for longer periods because high temperatures and long periods tend to destroy the organic compounds responsible for the hydrophobicity (Debano and Krammes 1966; DeBano et al. 1998). Subsequent investigations showed that (1) water repellency changes very little when soil temperatures are less than $175^{\circ} \mathrm{C}$ (DeBano 1981; Neary et al. 1999); (2) heating between $175^{\circ}$ and $200^{\circ} \mathrm{C}$ creates intense water repellency (DeBano 1981; March et al. 1994; Neary et al. 1999); (3) destruction of water repellency occurs when soils are heated between $280^{\circ}$ and $400^{\circ} \mathrm{C}$ (Savage 1974; DeBano et al. 1976; March et al. 1994; Giovannini and Lucchesi 1997); and (4) at temperatures of $450^{\circ} \mathrm{C}$ and above, virtually all organic material in the soil is consumed (Neary et al. 1999). An important caveat here is that the hydrophobic layer produced during fire can vary greatly due to differences in fire intensity and soil characteristics.

\section{STUDY METHODS}

This study investigates hand-piled slash burning effects on soil physical characteristics because much of the forest thinning and fuel reduction conducted in the Flagstaff, Arizona Urban/Wildland Interface Program involves hand-piled slash burning by the Fuels Management Team of Flagstaff's fire department. We also avoided the use of heavy equipment because it could be severely detrimental to the arboretum grounds and so contrary to the mission of the restoration program.

Piles were constructed from various sizes of slash, including needle litter, branches, and poles that were too small $(<15 \mathrm{~cm}$ [6 in]) to be removed by the harvesting crew. These slash sizes were grouped into classes and the percentages of the different size classes making up the piles were determined by measuring slash piles at the NAU Ecological Restoration Institute and the School of Forestry's research area in Fort Valley outside of Flagstaff. This process allows all slash piles to be constructed in a similar manner at the arboretum sites.
Infiltration rates were measured using a doublering infiltrometer following the sampling of soils. Infiltration was measured in the burned, unburned, and control plots. The measurements took place near the center of the plot but not adjacent to the soil sampling spot. The information gathered is used to determine whether or not burning has any effect on soil infiltration capacity. If burning has created hydrophobic soils, then the rate of infiltration should become momentarily zero after the surface of the soil becomes saturated, and before water starts to penetrate the hydrophobic layer.

Discrete values of soil moisture content were measured using time domain reflectometry (TDR; Soilmoisture Equipment Corp. 1996). Probes of 15 $\mathrm{cm}$ in length were inserted vertically into the ground near the center of every plot as well as approximately $60 \mathrm{~cm}$ outside the plot (because TDR measures are simple and quick, it was practical to measure outside the test plots as well as the control sites, to help account for any microsite variability to which groundwater might be subject). This measurement occurred at the same time that soil samples were gathered for lab analysis. Time domain reflectometry measures the amount of time needed for an electrical pulse to travel to the end of the probes and back again. Because moisture is the principal conductive agent in soils, measuring the time elapsed for the electrical pulse to travel becomes an indirect indicator of the soil moisture content. The equipment is carefully calibrated to reflect the moisture content.

Bulk density is the amount of soil particles (matter) in a volume of soil. The core method was used to calculate bulk density. In this method, cores of soil were taken near the center of the plots according to the procedures laid out in Soil Sampling and Methods of Analysis (Carter 1993). In this process, pits were dug to about $15 \mathrm{~cm}$ deep. Then the soil was scraped away from one of the walls to access undisturbed soil. The corer was placed horizontally against this undisturbed wall of soil, centered at $5 \mathrm{~cm}$ of depth, and tapped into the undisturbed soil column using a rubber mallet. Thus a core of soil was extracted from a single layer of soil (centered at $5 \mathrm{~cm}$ ). The ends of the cores were then capped (to maintain the cylindrical volume of soil) and transported to Northern Arizona University in Flagstaff for analysis.

Soil bulk density was analyzed in the School of Forestry Hydrology Lab at Northern Arizona University. Analysis was conducted according to the methods in Soil Sampling and Methods of Analysis (Carter 1993). The soil cores were weighed along 
with the coring tubes and the caps for the tubes. The cores were then oven dried in their tubes for 72 hours at $105^{\circ} \mathrm{C}$. When dry, the cores, tubes, and caps were weighed again and the difference between the first and the second weights indicated the amount of moisture in the soil. Bulk density ( $\mathrm{grams} / \mathrm{cm}^{3}$ ) was then calculated by dividing the weight (grams) of the dried soil by the volume $\left(\mathrm{cm}^{3}\right)$ of the soil core.

Statistical analysis was conducted using SPSS (SPSS 11.5, SPSS Inc.). Infiltration rates of treatment plots were compared to each other at initial and final time periods. All analyses used one-way ANOVA comparisons of each plot treatment (large, small, burned, unburned, and control). We conducted normality and homogeneity of variance tests and accounted for alpha inflation by using Tukey's HSD correction. In this study we selected a statistical significance level of $\alpha=0.05$.

\section{RESULTS}

Generally, soil bulk density was highest in the large burned sites and lowest in the large unburned sites (Figure 1). However, the bulk density values in the entire suite of treatment plots and the control ranged only from 1.1 to $1.24 \mathrm{~g} / \mathrm{cm}^{3}$. Thus, very little variation occurred regardless of treatment. In fact, no significant differences in bulk density occurred between any of the treatments at the 95 percent, or even the 90 percent confidence level.

Infiltration capacity measurements demonstrate distinct differences among almost all of the different treatments ( $p$ values range from $>0.001$ to 0.018 ). The only exception is that the infiltration capacity of soils in small burned plots was not significantly different from that in the control sites $(p=0.76)$. It is interesting, however, that the treatment data showed no distinct differences among treatments in the patterns of infiltration. All treatments show high initial infiltration rates that reduce to a constant rate within a short period of about 15 minutes (Figure 2). Typically, the infiltration rate values become constant at about 2 liters/ hour. The resulting pattern in turn indicates the absence of any significant formation of hydrophobic layers in the soils.

There are some significant differences (at the 0.05 confidence level) between treatments in soil moisture content, but these might be due to an interaction of two or more factors. One such difference is between large burned pile plots $(L+B)$

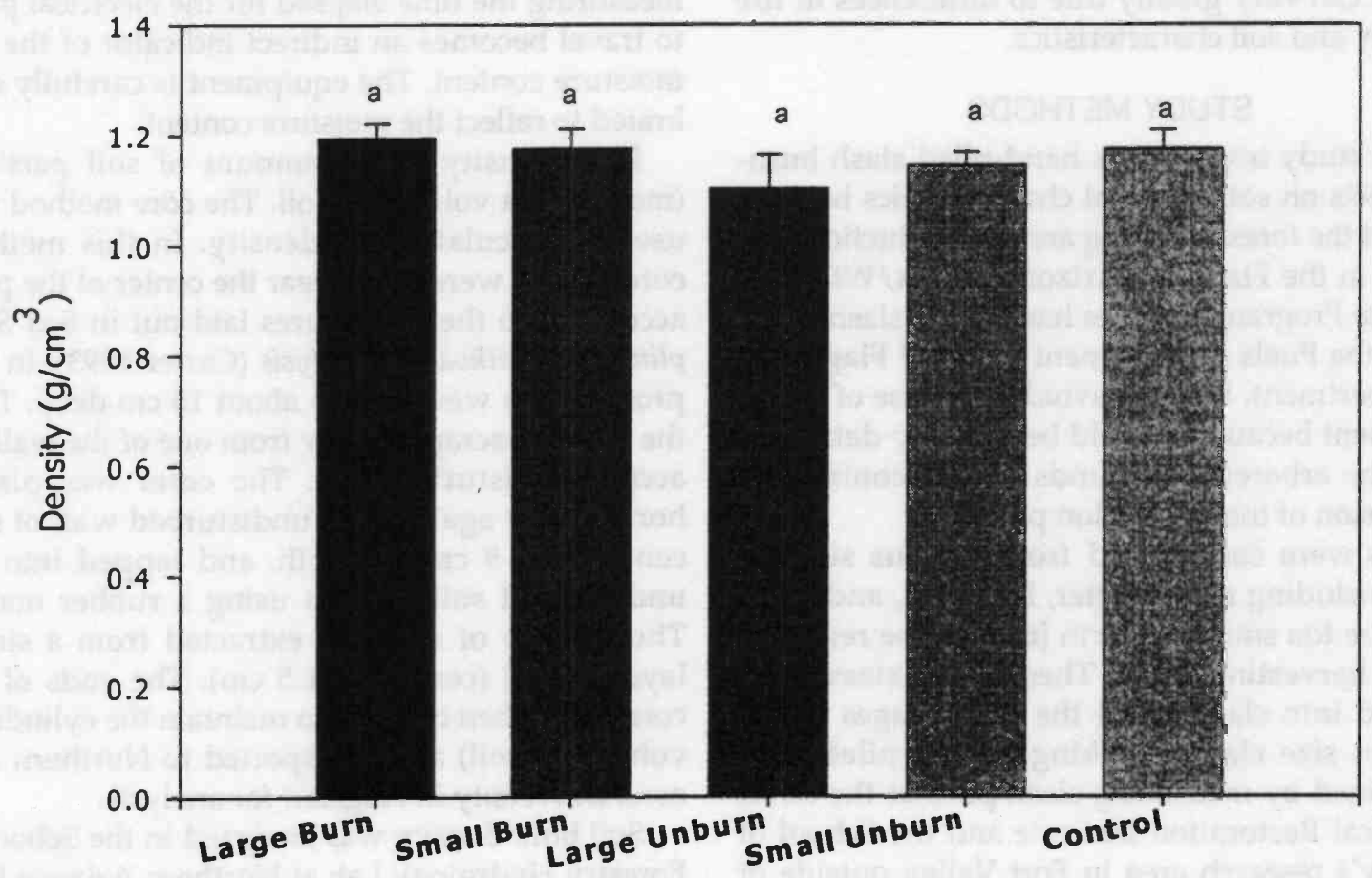

Figure 1. Soil bulk density after treatment. Similar letters indicate an absence of difference at $\alpha=0.05$. Although the burned plots did have a slightly higher density than the other treatment plots, the differences were not significant at the 0.05 level. 

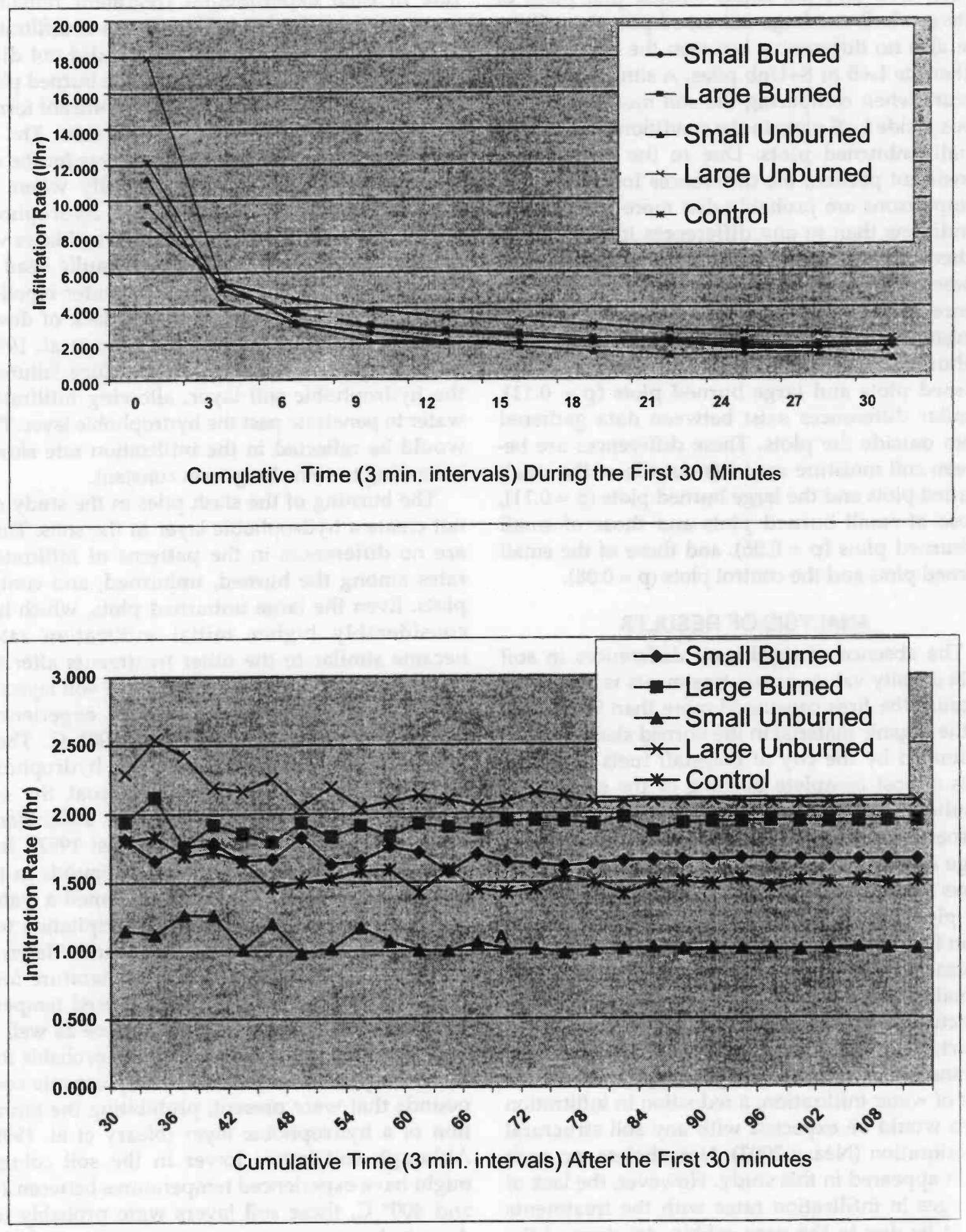

Figure 2. Rates of water infiltration (a) during the first 30 minutes and (b) after the first 30 minutes. The final, conste rates for the large burned and unburned plots differ significantly from the small unburned plots $(\alpha=0.05)$. Howev the pattern of rate decline is similar across all treatment types, which suggests that slash pile bumina did not dr tically impact infiltration. 
and small unburned (S+Unb) pile plots (Figure 3). However, there are no significant differences between $\mathrm{L}+\mathrm{B}$ and the small burned pile plots or between $L+B$ and large unburned pile plots. There are also no differences between the controls and either the $\mathrm{L}+\mathrm{B}$ or $\mathrm{S}+\mathrm{Unb}$ piles. A similar situation occurs when comparing the soil moisture conditions inside $\mathrm{L}+\mathrm{B}$ plots to the conditions outside the small unburned plots. Due to the lack of any consistent pattern, the differences found in these comparisons are probably due more to microsite conditions than to any differences in treatments. Other differences that are worthy to note do exist. These differences are at or around the 0.10 confidence level. The differences are between the soil moisture contents in large burned plots and large unburned plots $(p=0.06)$, and those in small burned plots and large burned plots $(p=0.11)$. Similar differences exist between data gathered from outside the plots. These differences are between soil moisture contents outside of the small burned plots and the large burned plots $(p=0.11)$, those of small burned plots and those of small unburned plots $(p=0.06)$, and those of the small burned plots and the control plots $(p=0.08)$.

\section{ANALYSIS OF RESULTS}

The absence of significant differences in soil bulk density values across treatments is intriguing because the fires consumed more than 95 percent of the organic material in the burned slash piles, as estimated by the city of Flagstaff fuels manager. This almost complete burning of the slash piles resulted in copious accumulation of ash in the burned plots, which should have introduced a large amount of fine particles into the soil macropores and thus affected the bulk density values of the plots regardless of compaction or heat effects from fire. Further, fires generating ground temperatures between 220 and $460^{\circ} \mathrm{C}$ consume the organic matter in the soil, leading to a deteriorated soil structure (DeBano et al. 1998). Deterioration in soil structure in turn leads to a loss of soil macropores. Because macropores are largely responsible for the rate of water infiltration, a reduction in infiltration rates would be expected with any soil structural deterioration (Neary 2003). Nonetheless, no such effect appeared in this study. However, the lack of changes in infiltration rates with the treatments could be due to the very cobbly structure of the soils that create channels for water movement (Brady 1996).

Although infiltration capacity does show distinct differences between different treatments, the patterns of infiltration rates remain the same (see Figure 2); after the first 18 minutes the infiltration rate in each experimental treatment remained constant at 1.0-2.2 L/hr. The pattern of infiltration in the control and unburned plots did not differ from the pattern of infiltration in the burned plots; this indicates the absence of any significant formation of hydrophobic layers in the soils. The expected pattern in the burned plots was for the soil infiltration rate to decrease rapidly when the percolating water encountered a hydrophobic layer in the soil. When the wettable soil layer was saturated, pressure, from the hydraulic head, at the boundary of the wetted and water-repellent layers would be increased by the lack of downward or lateral movement (DeBano et al. 1998). Eventually this pressure would induce failure in the hydrophobic soil layer, allowing infiltrating water to penetrate past the hydrophobic layer. This would be reflected in the infiltration rate slowly increasing to some long-term constant.

The burning of the slash piles in the study did not create a hydrophobic layer in the soils. There are no differences in the patterns of infiltration rates among the burned, unburned, and control plots. Even the large unburned plots, which had considerably higher initial infiltration rates, became similar to the other treatments after the initial $3 \mathrm{~min}$. It is almost certain that soil layers at some distance below the surface experienced temperatures between 280 and $400^{\circ} \mathrm{C}$. These temperatures would vaporize the hydrophobic compounds into gases that can coat the soil particles (Savage 1974; DeBano et al. 1976; March et al. 1994; Giovannini and Lucchesi 1997). It is possible that the hydrophobic compounds in the soil near the surface had not yet formed a waterrepellent layer and that further precipitation was required to transport those compounds down to some soil layer. However, as the literature indicates that any slash pile fires produced temperatures exceeding $450^{\circ} \mathrm{C}$ on the surface as well as slightly below the surface, it is more probable that the slash pile fires incinerated any organic compounds that were present, prohibiting the formation of a hydrophobic layer (Neary et al. 1999). Although soil layers lower in the soil column might have experienced temperatures between 280 and $400^{\circ} \mathrm{C}$, these soil layers were probably too deep to have enough organic matter to form an uninterrupted hydrophobic layer.

There were significant differences (at the $95 \%$ significance level) in soil moisture content between some of the plots subjected to different treatment 


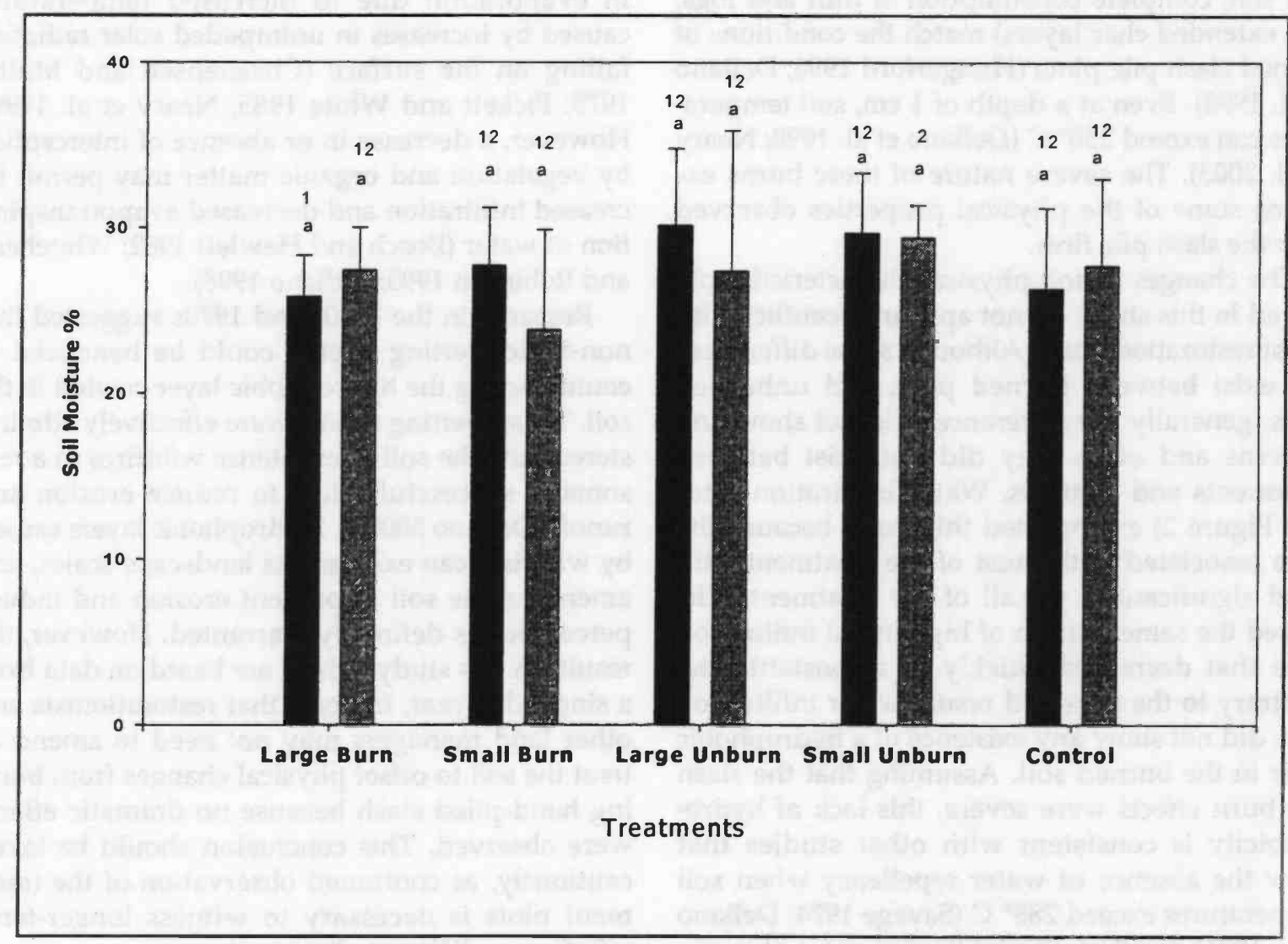

Figure 3. Soil moisture content in plots after treatment. The first bar of the pair depicts soil moisture content inside plots and the second bar indicates the level of moisture $1 \mathrm{ft}$ outside the plots. Similar letters indicate an absence difference when comparing moisture levels of inside plots to inside plots and outside to outside at $\alpha=0.05$. Differe numbers indicate differences between soil moisture content inside the plots compared to that outside the plots. 1 significantly different from 2 at $\alpha=0.05$.

types, but these differences appear erratic and are most likely not ecologically meaningful. One such difference was between large burned pile plots $(\mathrm{L}+\mathrm{B})$ and small unburned $(\mathrm{S}+\mathrm{Unb})$ pile plots. However there were no differences between $L+B$ and small burned pile plots nor were there differences between $L+B$ and large unburned pile plots. There were also no differences between the controls and either the $\mathrm{L}+\mathrm{B}$ or $\mathrm{S}+\mathrm{Unb}$ pile plots. Consequently, neither the size nor the treatment of the pile plots seems to have a significant effect on soil moisture content under the conditions prevailing in the study area during the study period. Although the difference appears to be due to an interaction of size and treatment, soil moisture data from outside the plots suggest otherwise. Whereas the soil moisture content inside the $\mathrm{L}+\mathrm{B}$ plots was significantly different from that inside the S+Unb plots, the moisture content outside the
S+Unb plots was similar to the content inside th S+Unb plots (see Figure 3). Both the inside and outside soil moisture content of S+Unb plots differed equally from other treatment types, so the significant difference observed between the mois ture content inside the $\mathrm{L}+\mathrm{B}$ plots and the content inside the $\mathrm{S}+\mathrm{Unb}$ plots is most likely due to differ ences in microsite conditions existing at the small burned sites, and probably not to differences in treatment.

\section{SUMMARY, CONCLUSIONS, AND RECOMMENDATIONS}

In much of the southern Colorado Plateau, burning of slash piles is generally conducted in association with forest restoration thinning. Although ground and belowground temperatures were not measured in this study, descriptions of high-severity fire effects (including reddish min- 
eral soil, complete consumption of duff and logs, and extended char layers) match the conditions of burned slash pile plots (Hungerford 1996; DeBano et al. 1998). Even at a depth of $1 \mathrm{~cm}$, soil temperatures can exceed $250^{\circ} \mathrm{C}$ (DeBano et al. 1998; Neary et al. 2003). The severe nature of these burns explains some of the physical properties observed after the slash pile fires.

The changes in soil physical characteristics observed in this study do not appear to conflict with forest restoration goals. Although some differences did exist between burned plots and unburned plots, generally the differences did not show any patterns and often they did not exist between treatments and controls. Water infiltration rates (see Figure 2) exemplified this point because the rates associated with most of the treatments differed significantly, yet all of the treatments displayed the same pattern of high initial infiltration rates that decreased quickly to a constant rate. Contrary to the expected result, water infiltration rates did not show any existence of a hydrophobic layer in the burned soil. Assuming that the slash pile burn effects were severe, this lack of hydrophobicity is consistent with other studies that show the absence of water repellency when soil temperatures exceed $288^{\circ} \mathrm{C}$ (Savage 1974; DeBano et al. 1976). Further, the infiltration rates of largepile plots are not slower than the rates of smallpile plots, regardless of whether or not the piles had been burned. This suggests that the amount of ash fines from the burned piles entering the macropores in the soil was insignificant, which corresponds to the results displayed by soil bulk density analysis. Bulk density did not indicate the expected increase associated with compaction of the soil from piling the slash, nor did bulk density increase in the burned plots due to fine particles associated with the ash (see Figure 1).

Soil moisture content displayed a difference (albeit not significant) between the large burned slash pile plots and the large unburned slash pile plots $(p=0.06)$, which would indicate a potential effect from intense burns of long duration on the soil. However, soil moisture within the large burned plots failed to differ from the moisture content in controls adjacent to, and outside of, the large burned plots $(p=0.614)$. The moisture levels in the large burned plots also failed to differ from the moisture content in the control plots $(\mathrm{p}=$ 0.814 ). According to these results, soil moisture is not significantly affected by the treatments in this study. This result is inconsistent with the idea that newly burned soil surfaces would have an increase in evaporation due to increased temperatures caused by increases in unimpeded solar radiation falling on the surface (Christensen and Muller 1975; Pickett and White 1985; Neary et al. 1999). However, a decrease in or absence of interception by vegetation and organic matter may permit increased infiltration and decreased evapotranspiration of water (Bosch and Hewlett 1982; Whitehead and Robinson 1993; DeBano 1998).

Research in the 1960s and 1970s suggested that non-ionic wetting agents could be beneficial in counteracting the hydrophobic layer created in the soil. These wetting agents were effectively administered onto the soil after intense wildfires in a reasonably successful effort to reduce erosion and runoff (DeBano 2000b). Hydrophobic layers caused by wildfires can exist across landscape scales, and amending the soil to prevent erosion and induce percolation is definitely warranted. However, the results in this study, which are based on data from a single dry year, indicate that restorationists and other land managers may not need to amend or treat the soil to offset physical changes from burning hand-piled slash because no dramatic effects were observed. This conclusion should be taken cautiously, as continued observation of the treatment plots is necessary to witness longer-term effects over different climatic stresses.

A major goal of forest restoration treatments in the Southwest is to thin the ponderosa pine overstory in an effort to reduce catastrophic wildfires as well as to promote understory health to levels of diversity and structure that are both socially and ecologically desirable. We must be careful that the methods we use to restore these forests do not compromise the overall goals that we strive to achieve. To this end, it is important to uncover the mechanisms that may or may not result in habitat reduction for native fauna, and that have broad implications for ecological functions, processes, and management. This study has demonstrated that initial (first-year) changes in soil infiltration capacity, soil moisture content, and bulk density due to burning of slash piles are not causal mechanisms of habitat reduction because profound changes in these soil characteristics did not occur.

\section{ACKNOWLEDGMENTS}

We thank The Arboretum at Flagstaff for their constant cooperation. We also thank Boris Poff, Pat Phillips, and the Ecosystem Ecology Lab in the School of Forestry for their assistance in field sampling as well as the Flagstaff Fire Department's Fuels Management Crew for managing the slash 
pile burns. Funding for this study came from the Bureau of Land Management (Grant PAA-01-7002) through the Ecological Restoration Institute at Northern Arizona University, and the State of Arizona Proposition 301, the National Science Foundation's Sustainability of Semi-Arid Hydrology and Riparian Areas (SAHRA; Grant Y542104), and the USDA Forest Service, Rocky Mountain Research Station (Grant 01-JV-11221606-214).

\section{LITERATURE CITED}

Bayliss, J. S. 1911. Observations on Marasmius oreades and Clitocybe gigantean as parasitic fungi causing fairy rings. Journal of Economic Biology 6: 111-132.

Blake, G. R., and K. H. Hartge. 1986. Bulk density. In Methods of soil analysis, Part 1, by A. Klute, pp. 363375. Agronomy 9, American Society of Agronomy, Madison WI.

Bosch, J. M., and J. D. Hewlett. 1982. A review of catchment experiments to determine the effect of vegetation changes on water yield and evapotranspiration. Journal of Hydrology 55: 3-23.

Brady, N. C., and R. R. Weil. 1996. The nature and properties of soils, 11 th ed., pp. 446-486. Prentice Hall, New Jersey.

Brown, J. K., J. A. K. Snell, and D. L. Bunnell. 1977. Handbook for predicting slash weight of western conifers. USDA Forest Service, General Technical Report INT-37.

Carter, M. R. 1993. Soil sampling and methods of analysis, pp. 330-332. Lewis Publishers, Boca Raton FL.

Christensen, N. L., and C. H. Muller. 1975. Effects of fire on factors controlling plant growth in adenostoma chaparral. Ecological Monographs 45: 29-55.

Covington, W., P. Fule, M. Moore, S. Hart, T. Kolb, J. Mast, S. Sackett, and M. Wagner. 1997. Restoring ecosystem health in ponderosa pine forests of the Southwest. Journal of Forestry 95 (4): 23-29.

DeBano, L. F. 1969. Observations on water repellent soils in the western United States. In Proceedings of a Conference on Water Repellent Soils, Riverside CA, edited by L. F. DeBano and J. Letey, pp. 17-29.

DeBano, L. F. 1981. Water repellent soils: A state of the art. USDA Forest Service, General Technical Report PS W-46. 21 pp.

DeBano, L. F. 2000a. Water repellency in soils: A historical overview. Journal of Hydrology 231-232: 4-32.

DeBano, L. F. 2000b. The role of fire and soil heating on water repellency in wildland environments: A review. Journal of Hydrology 231-232: 195-206.

DeBano, L. F., and J. S. Krammes. 1966. Water repellent soils and their relation to wildfire temperatures. International Association of Hydrological Sciences 2: 1419.

DeBano, L. F., S. M. Savage, and D. A. Hamilton. 1976. The transfer of heat and hydrophobic substances during burning. Soil Science Society of America Journal 40: 779-782.

DeBano, L. F., D. Neary, and P. Ffolliett. 1998. Fire's effects on ecosystems. John Wiley \& Sons, New York.

Fisher, R. F., and D. Binkley. 2000. Ecology and management of forest soils. John Wiley \& Sons, New York.

Freeman, D. R., R. M. Loomis, and P. J. Roussopoulos. 1982. Handbook for predicting slash weight in the Northeast. USDA Forest Service, General Technical Report NC-75.
Giovannini, G., and S. Lucchesi. 1997. Modifications induced in the soil physio-chemical parameters by experimental fires at different intensities. Soil Science 162: $479-486$.

Hardy, C. C. 1966. Guidelines for estimating volume, biomass, and smoke production for piled slash. USDA Forest Service, General Technical Report PNW-GTR364.

Hillel, D. 1971. Soil and water: Physical principles and processes. Academic Press, New York.

Hungerford, R. D. Soils. 1996. Fire in Ecosystem Management Notes: Unit II-I. USDA Forest Service, National Advanced Resource Technology Center, Marana AZ.

Lawes, J. B., J. H. Gilbert, and R. Warrington. 1883. Contribution to the chemistry of fairy rings. Journal of Chemical Society (London) 43: 208-223.

March, R. J., X. Arias, and A. Sole. 1994. Effects of slash burning on some soil physical properties on an olmoak coppice. In Soil erosion and degradation as a consequence of forest fires, edited by M. Sala and J. F. Rubio, pp. 29-42. Selection of papers from the International Conference on Soil Erosion and Degradation As a Consequence of Forest Fires, Barcelona, Spain. Geoforma ediciones, Logrono, Spain.

Martin, R. E., H. E. Anderson, W. D. Boyer, J. H. Dieterich, S. N. Hirsh, V. J. Johnson, and W. H. McNab. 1979. Effects of fire on fuels: A state of knowledge review. USDA Forest Service, General Technical Report WO-13.

Molliard, M. 1910. De l'action du Marasius oreades Fr. Sur la vegetation. Bulletin of the Society of Botany 57 (1): $62-69$

Mutch, R. W., S. F. Arno, J. K. Brown, C. E. Carlson, R. D. Ottmar, and J. L. Peterson. 1993. Forest health in the Blue Mountains: A management strategy for fireadapted ecosystems. USDA Forest Service, General Technical Report PNW-GTR-310.

Neary, D. G., C. C. Klopatek, L. F. DeBano, and P. F. Ffolliott. 1999. Fire effects on belowground sustainability: A review and synthesis. Forest Ecology and Management 122: 51-71.

Neary, D. G., G. J. Gottfried, L. F. DeBano, and A. Tecle. 2003. Impacts of fire on watershed resources. Journal of Arizona-Nevada Academy of Science 35: 23-41.

Pickett, S., and P. S. White. 1985. The ecology of natural disturbances and patch dynamics. Academic Press, San Diego CA.

Pyne, S. J., P. L. Andrews, and R. D. Laven. 1996. Introduction to wildland fire. John Wiley \& Sons, New York.

Sackett, S. S., S. M. Haase, and M. G. Harrington. 1996. Prescribed burning in southwestern ponderosa pine. In Effects of fire on Madrean Province ecosystems: A symposium proceedings, technical coordinators $\mathrm{P}$. F. Ffolliott, L. F. DeBano, M. B. Baker, Jr., G. H. Gottfried, G. Solis-Garza, C. B. Edmister, D. G. Neary, L. S. Allen, and R. H. Hamre, pp. 178-186. USDA Forest Service, General Technical Report RM-GTR-289.

Savage, S. M. 1974. Mechanisms of fire indices water repellency in soil. Soil Science Society of America Proceedings 33: 405-409.

Smith, D. M., B. C. Larson, M. J. Kelty, P. Mark, and S. Ashton. 1997. The practice of silviculture: Applied forest ecology, pp. 203-205. John Wiley \& Sons, New York.

Snell, J. A. K., and J. K. Brown. 1980. Handbook for predicting residue weights of Pacific Northwest conifers. USDA Forest Service, General Technical Report PSW103. 
Soilmoisture Equipment Corporation. 1996. Handbook for trase time domain reflectrometry system. Santa Barbara CA.

USDA 1995. Terrestrial ecosystem survey of the Coconino National Forest. USDA Forest Service, Southwestern Region.

USDA 1998. A guide to the Grand Canyon Forest Partnership: Working together in Flagstaff's urban wildland Interface. USDA Forest Service, Flagstaff AZ.

Whitehead, P. G., and M. Robinson. 1993. Experimental basin studies-An international and historical perspective of forest impacts. Journal of Hydrology 145: $217-230$. 